\title{
Effects of Brazil's Political Crisis on the Science Needed for Biodiversity Conservation
}

\begin{abstract}
William E. Magnusson 1*, Carlos E. V. Grelle ${ }^{2}$, Márcia C. M. Marques ${ }^{3}$, Carlos F. D. Rocha ${ }^{4}$, Braulio Dias ${ }^{5}$, Carla S. Fontana 6 , Helena Bergallo ${ }^{4}$, Gerhard E. Overbeck ${ }^{7}$, Mariana M. Vale ${ }^{2}$, Walfrido M. Tomas $^{8}$, Rui Cerqueira ${ }^{2}$, Rosane Collevatti ${ }^{9}$, Valério D. Pillar ${ }^{10}$, Luiz R. Malabarba ${ }^{11}$, Ana Carolina Lins-e-Silva ${ }^{12}$, Selvino Neckel-Oliveira ${ }^{13}$, Bruno Martinelli ${ }^{14}$, Alberto Akama ${ }^{15}$, Domingos Rodrigues ${ }^{16}$, Luis F. Silveira ${ }^{17}$, Aldicir Scariot ${ }^{18}$ and Geraldo W. Fernandes ${ }^{19}$

${ }^{1}$ Coordenação de Biodiversidade, Instituto Nacional de Pesquisas da Amazônia, Manaus, Brazil, ${ }^{2}$ Departamento de Ecologia, Universidade Federal do Rio de Janeiro, Rio de Janeiro, Brazil, ${ }^{3}$ Departamento de Botânica, SCB, Universidade Federal do Paraná, Curitiba, Brazil, ${ }^{4}$ Departamento de Ecologia, Universidade do Estado do Rio de Janeiro, Rio de Janeiro, Brazil, ${ }^{5}$ Departamento de Ecologia, Universidade de Brasília, Brasilia, Brazil, ${ }^{6}$ PUCRS, Museu de Ciências e Tecnologia, Porto Alegre, Brazil, ${ }^{7}$ Departamento de Botânica, Universidade Federal do Rio Grande do Sul, Porto Alegre, Brazil, ${ }^{8}$ Centro de Pesquisa Agropecuária do Pantanal, Empresa Brasileira de Pesquisa Agropecuária, Corumbá, Brazil, ${ }^{9}$ Instituto de Ciências Biológicas, Universidade Federal de Goiás, Goiânia, Brazil, ${ }^{10}$ Departamento de Ecologia, Universidade Federal do Rio Grande do Sul, Porto Alegre, Brazil, ${ }^{11}$ Departamento de Zoologia, Universidade Federal do Rio Grande do Sul, Porto Alegre, Brazil, ${ }^{12}$ Departamento de Biologia, Universidade Federal Rural de Pernambuco, Recife, Brazil, ${ }^{13}$ Departamento de Ecologia e Zoologia, Universidade Federal de Santa Catarina, Florianópolis, Brazil, ${ }^{14}$ PPG Desenvolvimento, Sociedade e Cooperação Internacional, UnB, Brasilia, Brazil, ${ }^{15}$ Museu Paraense Emilio Goeldi, Belém, Brazil, ${ }^{16}$ Instituto de Ciências Naturais, Humanas e Sociais, Universidade Federal de Mato Grosso, Sinop, Brazil, ${ }^{17}$ Museu de Zoologia, Universidade de São Paulo, São Paulo, Brazil, ${ }^{18}$ Embrapa Genetic Resources and Biotechnology (Cenargen), Brasília, Brazil, ${ }^{19}$ Departmento de Biologia Geral, Universidade Federal de Minas Gerais, Belo Horizonte, Brazil
\end{abstract}

The effects of Brazil's political crisis on science funding necessary for biodiversity conservation are likely to be global. Brazil is not only the world's most biodiverse nation, it is responsible for the greater part of the Amazon forest, which regulates the climate and provides rain to much of southern South America. Brazil was a world leader in satellite monitoring of land-use change, in-situ biodiversity monitoring, reduction in tropical-forest deforestation, protection of indigenous lands, and a model for other developing nations. Coordinated public responses will be necessary to prevent special-interest groups from using the political crisis to weaken science funding, environmental legislation and law enforcement.

Keywords: Brazil, biodiversity, climate change, governance, funding

\section{DRACONIAN CUTBACKS IN SCIENCE FUNDING}

Reductions in science funding are occurring across the Globe, but the recent political-economic crisis has plummeted Brazil from one of the most innovative countries in terms of science and conservation to a position of uncertainty. Recent articles have described recent drastic reductions in general science funding (e.g., Angelo, 2017; Siqueira and Rocha, 2017) and in funding of specific projects related to biodiversity in Brazil, such as the Brazilian Program for Biodiversity Research-PPBio (Fernandes et al., 2017). These reductions should also be seen in the context of the continuous inability of the Brazilian government to recognize the opportunities associated with being one of the world's most biodiverse nations, and the importance of biodiversity for ecosystem processes and societal well-being. 
In 2016 Brazil was surprised with the freezing of public investments on science, technology, innovation, education and health care for the next 20 years by the federal government (Siqueira and Rocha, 2017). In 2017, further bottlenecks in science, technology, and innovation were put in place by a cut to the Ministry of Science, Technology, Innovation and Communication (MCTIC)'s budget by almost half, from US\$ 1.8 billion proposed in the Annual Budget Law to US\$ 1 billion (Brazil, 2017). This meant a cut of approximately $40 \%$ compared to 2016 , and almost $56 \%$ compared to 2014 , being, at that time, the lowest budget for science in Brazilian history (Angelo, 2017). Last January, the government passed the 2018 Annual Budget Law (Brazil, 2018) with an additional reduction in MCTIC's budget of about $19 \%$ in relation to 2017 . From the ca. US\$ 1.8 billion in 2010, the MCTIC budget increased to near US\$ 2 billion in 2013, with a decrease after 2014 (Angelo, 2017). The series of funding cutbacks after 2014 interrupted a strategic movement to increase Brazilian investment in Research and Development that started the decade before (Marques, 2017). In 2000, Brazil's expenditure in Research and Development (in terms of GDP) was $1.0 \%$ (when the world mean was of $2.057 \%$ ), and from 2006 on experienced a steady increase, reaching $1.198 \%$ by 2013 ( world mean $=2.063 \%$ ), then decreasing to $1.168 \%$ in 2014 ( world mean $=2.153 \%$ ). The reductions in Brazil's investment in research and development went against the trends in other countries and the mean world percentage of GDP invested in research and development reached 2.228 in 2015 (World Bank, 2018).

\section{EFFECTS OF POLICY CHANGES ON ENVIRONMENT AND ECONOMY}

Brazilian environmental legislation is among the most advanced in the world, even in comparison with highly developed countries, such as the USA and Australia. Nevertheless, enforcement is low and large companies can often avoid penalties even after being found guilty. For instance, the company responsible for Brazil's greatest environmental disaster, the Mariana/Rio Doce mudslide in 2015, has consistently avoided paying fines that were part of a previous agreement (Fernandes et al., 2016; Garcia et al., 2017). Recently the Brazilian government has proposed or passed a variety of initiatives and laws that threaten biodiversity conservation (Azevedo-Santos et al., 2017). Politicians associated with the agribusiness sector, known in Brazil as the "bancada ruralista" (Fearnside, 2016), successfully changed legislation relating to suppression of native vegetation to, among other things, absolve landowners who illegally cleared land in the past and to reduce the area around water courses in which native vegetation has to be restored (Soares-Filho et al., 2014). Conservation of native vegetation around watercourses is known to be one of the most effective means of avoiding erosion and maintaining stream flows during drought periods, and to provide corridors and connectivity for the terrestrial fauna (e.g., Sekercioglu et al., 2015). The major urban centers of Brazil, where most of the GNP is generated, have suffered from a lack of water in the catchments of the major dams (Nobre et al., 2016) and the cost of energy to consumers is regularly increased because expensive, highly-polluting, thermoelectric plants have to be used to complement hydro-electric power provided by the dams (Rosa, 2007). Additionally, the losses of native vegetation in the Cerrado savanna region in Central Brazil are altering the water balance through increased evapotranspiration and diminishing the capacity for water storage (Oliveira et al., 2013). Such land-use changes exacerbate the serious water shortages occurring frequently in southeastern Brazil (Guimarães, 2014). In addition, a draft of a new law on pesticides (PL 6299/2002), which loosens restrictions on pesticide use, was approved by the Special Committee of the Chamber of Deputies. Brazil already has the world's highest consumption of agrochemicals and weakening legislation will worsen the health of the population and endanger ecosystem services.

The efforts to undercut Brazilian environmental legislation is shortsighted as it creates predictable problems for agribusiness. Agriculture is highly dependent on water, which in turn is dependent on rainfall. The area with the greatest agricultural production in the country, in central and southern Brazil, depends heavily on the rainfall that comes from the Amazon (Marengo et al., 2004), which in turns depends on the maintenance of standing forest (Makarieva and Gorshkov, 2007; Oliveira et al., 2013; Makarieva et al., 2014). The Amazon, however, is rapidly approaching a tipping point where deforestation combined with fires and climate change will cause the forest to be replaced by degraded savanna-like vegetation (Lovejoy and Nobre, 2018). While there is theoretical and empirical evidence of impending ecosystem collapse, with drastic implications for agricultural productivity and human livelihoods, this tipping point can and should be avoided (Lindenmayer et al., 2016). Nonetheless, the Brazilian government has made little effort to avoid this imminent disaster. Between 2005 and 2012, the rate of deforestation in the Brazilian Amazon decreased steadily, mainly in consequence of policies to cut deforestation based on monitoring by the Brazilian Aerospace Agency (INPE) and law enforcement by the Brazilian Environmental AgencyIBAMA (Nepstad et al., 2014). Since 2013, however, deforestation rates have increased steadily. This period coincides with the reduction in funding for enforcement agencies, relaxation of environmental legislation, and a general sense of impunity because of politicians' inability to confront special-interest groups (Fearnside, 2016). It is hard to argue, however, that gains by forest clearing to a few people in the Amazon would compensate the risk for huge collective losses to water security and the general economy.

To understand the effects of such policies, new research and monitoring is necessary, as has been demonstrated repeatedly (Gardner, 2010). Brazil needs more science funding, but present budgetary policies are leading to a science blackout. Research funding must support local institutions, which often suffer from a vicious cycle of lack of funding leading to poor scientific output that justifies further cuts (Magnusson et al., 2016).

If Brazil is not to slip behind in international competition in an increasingly technological world, there is obviously a need for better science funding. Perhaps inclusion of a minimum of 2$3 \%$ of GNP in the Federal Constitution would be appropriate. 
However, that would not necessarily solve Brazil's problems in relation to biodiversity. Besides being the most biodiverse country, Brazil is high on the ranking of countries whose ecosystem services are most related to biodiversity (Marengo et al., 2004; Makarieva and Gorshkov, 2007). It is one of the few countries of sufficient size that internal policies could ameliorate the regional effects of climate change.

One important action would be to fund ecological analysis and synthesis that could provide information on biodiversity and critical ecosystem services to government for use in long-term planning. Politicians must recognize that biodiversity-related ecosystem services are as important as infrastructure, such as ports and roads, for maintaining the country's international competitivity. Biodiversity conservation should have special status in parliamentary discussions, because the services it provides are essential for all the special-interest groups lobbying for financial subsidies. An important step in this direction has already been initiated by the National Council for Science and Technology-CNPq, which intends to create such a Center of Synthesis (http://www.cnpq.br/web/guest/noticiasviews/-/ journal_content/56_INSTANCE_a6MO/10157/6064830).

Although Brazil is a world leader in remote-sensing monitoring of biodiversity (Secades et al., 2014), its budget for in situ biodiversity monitoring was severely cut in the recent past (Fernandes et al., 2017; Overbeck et al., 2018). Furthermore, cuts in funding have had the greatest effect in some of the most important regions for ecosystem services (Magnusson et al., 2016). The Brazilian Biodiversity Research Program (PPBio) is one of the most effective systems for in situ monitoring of biodiversity and is being tried or replicated in other countries, such as Ecuador, Argentina, Liberia, Australia and Nepal. The Brazilian Long-Term Ecological-Research Site Network-PELD is one of the most extensive in the world and many sites are also integrated in the PPBio program. It is not possible to manage biodiversity and ecosystem services if we do not have enough data to analyze long-term trends, especially in relation to land use and climate change. This is especially true at the local level, where changes may have drastic effects on local people and indigenous cultures.

The lack of long-range modeling and integration of information on biodiversity and ecosystem services in government planning is certainly not unique to Brazil, though it is clear that Brazil has much to gain economically and culturally by integrated management of its ecosystems, perhaps much more so than most other countries. The change in the federal and state governments that will take place in 2019 may be an opportunity to reverse the trends in science funding and guarantee Brazil's competitiveness in an increasingly technological world.

\section{LOSS OF TRADITIONAL VALUES}

So far, we have discussed the economic value of biodiversity, but Brazil also contains the largest areas of indigenous lands on the continent, and biodiversity is fundamental to the cultural values of indigenous people. Indigenous groups have occupied South America for millennia, including extensive areas in the Amazon biome (Maretti et al., 2014), with low deforestation rates (Kronik and Verner, 2010). In Brazil, indigenous territories have also been shown to be of importance for conservation of ecosystems because most have considerable levels of effective protection (Kronik and Verner, 2010; Nolte et al., 2013; Carranza et al., 2014). By storing a crucial portion of carbon stock and reducing carbon emissions, Indigenous Reserves are nowadays strategic for slowing climate change in the Amazon, and thus the world (Kronik and Verner, 2010; Ricketts et al., 2010; Soares-Filho et al., 2010).

Brazil has an impressive record of decreeing indigenous lands, with over 700 indigenous territories covering more than $13 \%$ of the national continental territory. However, specialinterest groups used the political instability associated with the current crisis to change legislation and reduce the influence of FUNAI, the branch of the Brazilian government responsible for protection of indigenous rights. Indigenous lands, as well as various forms of sustainable-development reserves, are important for protecting biodiversity because they are inhabited by people interested in biodiversity conservation who will defend their boundaries (Adeney et al., 2009). Some efforts have been made to include indigenous knowledge in decision making, especially through the PNGATI policy (National Policy on Territorial and Environmental Management of Indigenous Lands; Brazil, 2012), but most scientific studies are still concentrated outside land set aside for traditional communities (Magnusson et al., 2016; Martins et al., 2017). It is essential to include funding for projects that integrate traditional and modern knowledge in plans for ecosystem management.

\section{WHAT SHOULD BE DONE}

Brazil's reduction in biodiversity conservation science is leading to an imminent collapse, which is not compatible with a country that is one of the largest economies in the world and that plays a central role for the planet's sustainability. Producing wealth and advancing scientific and technological development is a challenge for many developing nations. So, how to reverse the negative trends and resume capitalization of science, technology and biodiversity conservation in a country with so many demands for resources in the social area and that depends on a strengthened economy, hitherto based on commodities? The necessary actions include the following: (1) immediate reversal of the constitutional amendment (EC 95) that caps the federal government spending linearly irrespective of future increase in revenue, so that the scientific sector, the only one capable of reversing economic difficulties in the long term, can resume growth; (2) ensure that resources for research and development collected by companies and government ministries are applied in Brazilian science; (3) create a scientific observatory to monitor in the National Congress the processing of bills related to scientific and environmental issues. This observatory, with representatives of the academy, would have the function of lobbying congressional delegates in the decision making in this important area for Brazil and ensure that indigenous and other traditional inhabitants are effectively included in proposals to 
monitor and conserve biodiversity; (4) revise the laws that have been modified recently to reduce environmental protection. With action on these four fronts, biodiversity science could once again be a major protagonist for sustainable development in Brazil.

\section{AUTHOR CONTRIBUTIONS}

WM coordinated the project and CG collated the contributions. MM provided the perspective from Paraná; CR provided the perspective from Rio de Janeiro; BD provided a countrywide overview; GO provided the perspective from the Pampa region; MV provided the perspective from Brasília; WT provided the perspective from Mato Grosso do Sul; RCe provided the perspective from Rio de Janeiro; RCo provided the perspective from Goiania; VP provided the perspective from southern Brazil; LM provided the perspective from Rio Grande do Sul;

\section{REFERENCES}

Adeney, J. M., Christensen, N. L., and Pimm, S. L. (2009). Reserves protect against deforestation fires in the Amazon. PLoS ONE 4:e5014. doi: 10.1371/journal.pone.0005014

Angelo, C. (2017). Brazilian scientists reeling as federal funds slashed by nearly half. Nature. doi: 10.1038/nature.2017.21766

Azevedo-Santos, V. M., Fearnside, P. M., Oliveira, C. S., Padial, A. A., Pelicicle, F. M., Lima, D. P., et al. (2017). Removing the abyss between conservation science and policy decisions in Brazil. Biodiv. Cons. 26, 1745-1752. doi: 10.1007/s10531-017-1316-x

Brazil (2012). Decreto $N^{\circ} 7747$ de 5 de junho de 2012. Diário Oficial da União 6.6.2012. Available online at: https://www.planalto.gov.br/ccivil_03/_ato20112014/2012/decreto/d7747.htm

Brazil (2017). Projeto de Lei $n^{\circ}$ 18/2016-CN, de Lei Orçamentária Anual (LOA). Orçamento da União. Available online at: http://www2.camara.leg.br/ orcamento-da-uniao/leis-orcamentarias/loa/2017/tramitacao/texto-final

Brazil (2018). Lei $n^{\circ}$ 13.587, de 2 de Janeiro de 2018. Diário Oficial da União (Seção 1). (Accessed January 03, 2018), 1-3

Carranza, T., Balmford, A., Kapos, V., and Manica, A. (2014). Protected area effectiveness in reducing conversion in a rapidly disappearing ecosystem: the Brazilian Cerrado. Cons. Lett. 7, 216-223. doi: 10.1111/conl. 12049

Fearnside, P. M. (2016). Brazilian politics threaten environmental policies. Science 353, 764-748. doi: 10.1126/science.aag0254

Fernandes, G. W., Goulart, F. F., Ranieri, B. D., Coelho, M. S., Dales, K., Boesche, N., et al. (2016). Deep into the mud: ecological and socio-economic impacts of the dam breach in Mariana, Brazil. Nat. Cons. 14, 35-45. doi: 10.1016/j.ncon.2016.10.003

Fernandes, G. W., Vale, M. M., Overbeck, G. E., Bustamante, M. C., Grelle, C. E. V., Bergallo, H. G., et al. (2017). Dismantling Brazil's science threatens global biodiversity heritage. Perspectives in Ecol. Cons. 15, 239-243. doi: 10.1016/j.pecon.2017.07.004

Garcia, L. C., Ribeiro, D. B., Roque, F. O., Ochoa-Quintero, J. M., and Laurance, W. F. (2017). Brazil's worst mining disaster: Corporations must be compelled to pay the actual environmental costs. Ecol. Appl. 27, 5-9. doi: 10.1002/eap.1461

Gardner, T. (2010). Monitoring Forest Biodiversity. Oxford: The Earthscan Forest Library.

Guimarães, M. (2014). Dança da chuva. Pesquisa FAPESP 226, 18-25.

Kronik, J., and Verner, D. (2010). Indigenous peoples and climate change in Latin America and the Caribbean. Washington, DC: World Bank.

Lindenmayer, D., Messier, C., and Sato, C. (2016). Avoiding ecosystem collapse in managed forest ecosystems. Front. Ecol. Environ. 14, 561-568. doi: $10.1002 /$ fee. 1434
ACL provided the perspective from Recife; $\mathrm{SN}-\mathrm{O}$ provided the perspective from Santa Catarina; BM provided the perspective from the Science Ministry; AA provided the perspective from Pará; HB provided the perspective from the Atlantic Forest; DR provided the perspective from Mato Grosso; CF provided the perspective from southern Brazil; LS provided the perspective from São Paulo; AS provided the perspective from genetic resources; GF provided a perspective from Minas Gerais.

\section{FUNDING}

This article is a result of funding by the Brazilian Ministry of Science Technology Innovation and Communication for meetings to restructure its biodiversity program, CNPq/MCTICSEPED PPBio(441993/2016-8) which coincided with the financial crisis.
Lovejoy, T. E., and Nobre, C. T. (2018). Amazon tipping point. Sci. Adv. 4:eaat2340. doi: $10.1126 /$ sciadv.aat 2340

Magnusson, W. E., Ishikawa, N. K., Lima, A. P., Dias, D. V., Costa, F. M., de Holanda, A. S. S., et al. (2016). A linha de véu: a biodiversidade brasileira desconhecida. Parcerias Estratégicas 21, 45-60.

Makarieva, A. M., and Gorshkov, V. G. (2007). Biotic pump of atmospheric moisture as driver of the hydrological cycle on land. Hydrol. Earth Syst. Sci. 11, 1013-1033. doi: 10.5194/hess-11-1013-2007

Makarieva, A. M., Gorshkov, V. G., Sheil, D., Nobre, A. D., Bunyard, P., and Li, B. L. (2014). Why does air passage over forest yield more rain? examining the coupling between rainfall, pressure, and atmospheric moisture content. J. Hydrometeorol. 15, 411-426. doi: 10.1175/JHM-D-120190.1

Marengo, J. A., Soares, W. R., Saulo, C., and Nicolini, M. (2004). Climatology of the low-level jet east of the andes as derived from NCEP-NCAR reanalyses: characteristics and temporal variability. J. Climate 17, 2261-2280. doi: 10.1175/1520-0442(2004)017<2261:COTLJE >2.0.CO;2

Maretti, C. C., Riveros, S. J. C., Hofstede, R., Oliveira, D., Charity, S., Granizo, T., et al. (2014). State of the Amazon: Ecological Representation in Protected Areas and Indigenous Territories. Brasília;Quito: WWF Living Amazon (Global) Initiative.

Marques, F. (2017). Funding in crisis: alternatives for softening the impact of federal budget cuts on national research and development efforts. Revista Fapesp 256, 20-26.

Martins, E., Loyola, R. D., and Martinelli, G. (2017). Challenges and perspectives for achieving the Global strategy for plant conservation targets in Brazil. Ann. Missouri Bot. Gard. 102, 347-356. doi: 10.3417/D-16-0 0009A

Nepstad, D., McGrath, D., Stickler, C., Alencar, A., Azevedo, A., Swette, B., et al. (2014). Slowing amazon deforestation through public policy and interventions in beef and soy supply chains. Science 344, 1118-1123. doi: $10.1126 /$ science. 1248525

Nobre, C. A., Marengo, J. A., Seluchi, M. E., Cuartas, A., and Alves, L. M. (2016). Some characteristics and impacts of the drought and water crisis in Southeastern Brazil during 2014 and 2015. J. Water Res. Protec. 8, 252-262. doi: 10.4236/jwarp.2016.82022

Nolte, C., Agrawal, A., Silvius, K. M., and Soares-Filho, B. S. (2013). Governance regime and location influence avoided deforestation success of protected areas in the Brazilian Amazon. Proc. Natl. Acad. Sci. U.S.A. 110, 4956-4961. doi: $10.1073 /$ pnas. 1214786110

Oliveira, P. T. S., Nearing, M. A., Susan Moran, M., Goodrich, D., Wendland, E., and Gupta, H. V. (2013). Trends in water balance components across the Brazilian Cerrado. Water Resour. Res. 50, 7100-7114. doi: 10.1002/2013WR015202 
Overbeck, G. E., Bergallo, H. G., Grelle, C. E. V., Akama, A., Bravo, F., Colli, G. R., et al. (2018). Global biodiversity threatened by science budget cuts in brazil. Bioscience 68, 11-12. doi: 10.1093/biosci/bix130

Ricketts, T. H., Soares-Filho, B., da Fonseca, G. A., Nepstad, D., Pfaff, A., Petsonk, A., et al. (2010). Indigenous lands, protected areas, and slowing climate change. PLoS Biol. 8:e1000331. doi: 10.1371/journal.pbio.10 00331

Rosa, L. P. (2007). Hydroelectric, thermal and nuclear generation. Estudos Avançados 21, 39-58. doi: 10.1590/S0103-40142007000100005

Secades, C., O'Connor, B., Brown, C., Walpole, M., Skidmore, A., Wang, T., et al. (2014). Earth Observation for Biodiversity Monitoring: a Review of the Current Approaches and Future Opportunities for Tracking Progress Toward the Aichi Biodiversity Targets. Montréal Technical Series.Vol. 72. Montreal, QC. Secretariat of the Convention of Biological Diversity.

Sekercioglu, Ç. H., Loarie, S. R., Oviedo-Brenes, F., Mendenhall, C. D., Daily, G. C., and Ehrlich, P. R. (2015). Tropical countryside riparian corridors provide critical habitat and connectivity for seed-dispersing forest birds in a fragmented landscape. J. Ornithol. 156, 343-353. doi: 10.1007/s10336-015-1299-x

Siqueira, C. C., and Rocha, C. F. D. (2017). Brazil's public universities in crisis. Science 356: 812. doi: 10.1126/science.aan2527

Soares-Filho, B., Moutinho, P., Nepstad, D., Anderson, A., Rodrigues, H., Garcia, R., et al. (2010). Role of Brazilian amazon protected areas in climate change mitigation. Proclamation Natl. Acad. Sci. U.S.A. 107,10821-10826. doi: 10.1073/pnas.0913048107

Soares-Filho, B., Rajão, R., Macedo, M., Carneiro, A., Costa, A., Coe, M., et al. (2014). Cracking brazil's forest code. Science 344, 363-364. doi: $10.1126 /$ science. 1246663

World Bank (2018). Countries Research and Development Expenditure 2000-2014. Available online at: https://data.worldbank.org/indicator/GB.XPD.RSDV.GD. ZS

Conflict of Interest Statement: The authors declare that the research was conducted in the absence of any commercial or financial relationships that could be construed as a potential conflict of interest.

Copyright (๔) 2018 Magnusson, Grelle, Marques, Rocha, Dias, Fontana, Bergallo, Overbeck, Vale, Tomas, Cerqueira, Collevatti, Pillar, Malabarba, Lins-e-Silva, Neckel-Oliveira, Martinelli, Akama, Rodrigues, Silveira, Scariot and Fernandes. This is an open-access article distributed under the terms of the Creative Commons Attribution License (CC BY). The use, distribution or reproduction in other forums is permitted, provided the original author(s) and the copyright owner(s) are credited and that the original publication in this journal is cited, in accordance with accepted academic practice. No use, distribution or reproduction is permitted which does not comply with these terms. 